International Journal of Environmental Research and

\title{
Levels of Organochlorine Pesticides in Blood Plasma from Residents of Malaria-Endemic Communities in Chiapas, Mexico
}

Luz E. Ruiz-Suárez ${ }^{1, \dagger}$, Ricardo A. Castro-Chan ${ }^{1, \dagger}$, Norma E. Rivero-Pérez ${ }^{2}$, Antonio Trejo-Acevedo ${ }^{2}$, Griselda K. Guillén-Navarro ${ }^{1}$, Violette Geissen ${ }^{3}$ and Ricardo Bello-Mendoza ${ }^{1,4, \dagger}, *$

1 El Colegio de la Frontera Sur, Carretera Antiguo Aeropuerto Km. 2.5, C.P. 30700 Tapachula, Chiapas, Mexico; E-Mails: elizasuarez@hotmail.com (L.E.R.-S.); rcastro@ecosur.mx (R.A.C.-C.); kguillen@ecosur.mx (G.K.G.-N.)

2 Centro Regional de Investigación en Salud Pública, Instituto Nacional de Salud Pública, 19 Poniente y $4^{\mathrm{a}}$ Norte S/N, C.P. 30700 Tapachula, Chiapas, Mexico; E-Mails: nrivero@insp.mx (N.E.R.-P); trejo@insp.mx (A.T.-A.)

3 Alterra, Wageningen University and Research Center, P.O. Box 47, 6700AA Wageningen, The Netherlands; E-Mail: violette.geissen@wur.nl

4 Department of Civil and Natural Resources Engineering, University of Canterbury, Private Bag 4800, Christchurch 8140, New Zealand

$\dagger$ These authors contributed equally to this work.

* Author to whom correspondence should be addressed; E-Mail: ricardo.bellomendoza@canterbury.ac.nz; Tel.: +64-3-364-2987 (ext. 6407); Fax: +64-3-364-2758.

External Editor: Paul B. Tchounwou

Received: 25 July 2014; in revised form: 22 September 2014 / Accepted: 25 September 2014 / Published: 10 October 2014

\footnotetext{
Abstract: Organochlorine (OC) pesticides have been extensively used for pest control in agriculture and against malaria vectors in the region of Soconusco, Chiapas, in southern Mexico. Our study aimed to identify whether the inhabitants of four Soconusco communities at different locations (i.e., altitudes) and with different history of use of OC pesticides, have been similarly exposed to residues of these pesticides. In particular, we analyzed the potential relationship between levels of OC pesticides in plasma and the age, gender, and residence of the study population $(n=60)$. We detected seven pesticides in total $(\gamma-\mathrm{HCH}, \beta-\mathrm{HCH}$,
} 
heptachlor, p,p'-DDE, p,p'-DDT, $\beta$-endosulfan, endrin aldehyde). Of these, $\mathrm{p}, \mathrm{p}^{\prime}$-DDE and $\beta$-endosulfan were the most frequently found (in $98 \%$ and $38 \%$ of the samples, respectively). The low-altitude ( $<20 \mathrm{~m}$ above sea level; masl) and mid-altitude (520 masl) locations had the highest levels of p, $p^{\prime}$-DDE, with geometric means of $50.6 \mu \mathrm{g} / \mathrm{L}$ and $44.46 \mu \mathrm{g} / \mathrm{L}$, respectively. The oldest subjects (>60 years) had the highest p,p'-DDE level $(56.94 \pm 57.81 \mu \mathrm{g} / \mathrm{L})$ of all age groups, while men had higher p,p'-DDE $(34.00 \pm 46.76 \mu \mathrm{g} / \mathrm{L})$ than women. Our results demonstrate that residents of the Soconusco region are exposed to p,p'-DDE because of high exposure to DDT in the past and current environmental exposure to this DDT-breakdown product.

Keywords: environmental exposure; malaria; organochlorine pesticides; p,p'-DDE; $\beta$-endosulfan; Soconusco

\section{Introduction}

Soconusco is located in the state of Chiapas, in southeast Mexico, and is one of the most important agricultural regions in the country. Organochlorine (OC) pesticides were used for more than 40 years for pest control in this region, mainly in coffee and cotton fields. Cotton cultivation in particular grew remarkably, from 518 to 35,227 ha cultivated, in the 1950 to 1978 period [1]. This growth occurred with the adoption of modern agricultural technologies, particularly the use of insecticides. Official records indicate that a mixture of toxaphene and dichlorodiphenyltrichloroethane (DDT) was sprayed in doses of 6-7 L/ha per cycle [2]. Catalán [1] reported that spraying reached 21 times per cycle and that $1,109,650.5 \mathrm{~L} /$ year of insecticides were applied for pest control when the cultivated cotton acreage was the largest. Moreover, Soconusco has also been a major malarial area, so DDT was simultaneously used to control mosquitoes that transmit the disease, with six semestral applications of $2 \mathrm{~g} / \mathrm{m}^{2}$ of residential area on average [3,4]. It is estimated that 69,545 tons of DDT were used just during Mexican health campaigns in 1957-2000 [5]. OC pesticides are highly persistent in the environment because of their resistance to chemical and biological degradation. In addition, their solubility in lipids contributes to their bioaccumulation and biomagnification through food chains, increasing the potential risk to human health [6]. Exposure to OC pesticides increases health risks such as propensity to develop of cancer [7], reproductive effects [8], behavioral and neurological effects [9], and genotoxic effects $[10,11]$. There is also evidence that low-dose exposure to OC pesticides can be a risk factor for type 2 diabetes. Rignell-Hydbom et al. [12] reported an association between p,p'-DDE exposure and type 2 diabetes in a case-control study.

Because of the abundant use of pesticides in the Soconusco region, biomonitoring has been implemented to identify population groups with high exposure to OC pesticides. The results have demonstrated high levels of residues in biological and environmental samples. Yáñez et al. [13] reported that the breast milk from women living in Chiapas had higher levels of DDT and its main metabolite dichlorodiphenyldichloroethylene (DDE) than breast-feeding women from other states, including Oaxaca, Quintana Roo, and San Luis Potosi. Other studies have reported high levels of DDT and its metabolites in blood of children [3,4,14,15]. Notably, children in Chiapas had the highest levels of DDT 
and its metabolites out of all children participating in a study that covered several communities of Mesoamerican countries [3]. OC pesticides have also been found in the environment. Levels of chlordane, dieldrin, toxaphene, heptachlor, endosulfan, hexachlorocyclohexane, DDT, and DDE have been reported in air [16,17], while DDE, DDD, and $\alpha$-endosulfan were detected in water and sediments [18]. Moreover, high concentrations of DDT and its metabolites were found in fish samples from a coastal community in the region (San Simón) that was subject to intensive spraying of DDT for malaria control [19].

The history of use of OC pesticides in the Soconusco region varies by zone, which could have led to different levels of exposure for the population. The coastal plain (low altitude) of the region was exposed to intensive use of DDT for malaria control and pest control in cotton crops [1]. On the mountain slopes (mid-region), endosulfan and DDT were used in large quantities in coffee crops and for malaria control, respectively. There are no reports of the use of OC pesticides in high-altitude zones, but OC pesticides are believed to be used in lower quantities and frequencies for malaria control because these areas are difficult to access and less suitable for agriculture (mountainous area). In summary, each of these three zones has different geographical characteristics (altitude) and climatic conditions (e.g., temperature and precipitation) that can influence the spread and flow of OC pesticides. Transportation of OC pesticides within and between regions has been reported [16,20]. Therefore, zones with intense pesticide use could be considered exporters and other zones could be considered net importers of the contaminants. In line with this, Alegría et al. [16] reported higher levels of DDT and DDE in a mountainous region of Chiapas (1200 m above sea level; masl) where organic coffee is grown and no pesticides are used, compared to a station located in the coastal zone of the same region. It is unclear whether the population at different locations of the Soconusco region has been similarly exposed to OC pesticides. So far, no studies have been conducted in the region to provide information on this issue. Therefore, to identify whether the residents of different zones in the region have been equally exposed to OC residues, we collected and analyzed blood samples from 60 inhabitants of communities located in low-altitude zones (La Victoria and Buenos Aires), a midaltitude zone (Unión Roja), and a high-altitude zone (Agua Caliente) of Soconusco. Here, we demonstrate differences in the levels of OC pesticides in blood plasma according to age, gender, and town's altitude of selected residents of the Soconusco region in Chiapas, Mexico.

\section{Experimental Section}

\subsection{Study Area}

The study was conducted in four communities of the Soconusco region, which is considered endemic for malaria transmission and is located in the southeastern state of Chiapas, Mexico (Figure 1). The study region was classified into three zones based on differences in altitude, climate, and agricultural production system: low region (Buenos Aires and Victoria), mid-region (Unión Roja), and high region (Agua Caliente) (Table 1). 
Figure 1. Map of the Soconusco region of Chiapas (Mexico) showing the location of the communities surveyed in this study.

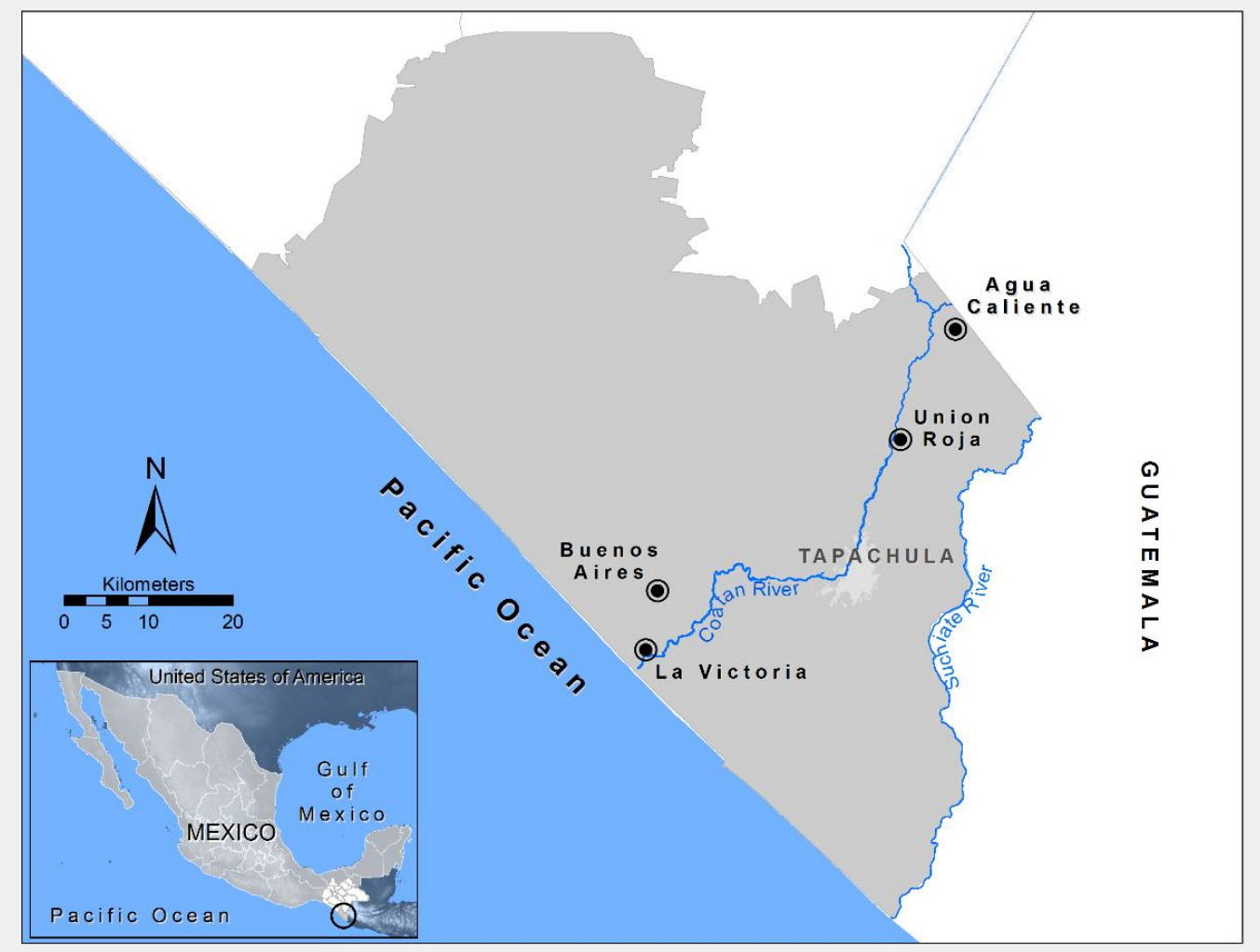

Table 1. Characteristics of the surveyed communities.

\begin{tabular}{|c|c|c|}
\hline Community & Zone & Characteristics * \\
\hline Agua Caliente & High & $\begin{array}{l}\text { Rural community located in a malaria-endemic region with agricultural activity, } \\
\text { mainly vegetables for consumption and other crops on a smaller scale (coffee, } \\
\text { corn). Humid temperate climate with average annual rainfall of } 3253 \mathrm{~mm} \text { and } \\
\text { average annual temperature of } 22^{\circ} \mathrm{C} \text {. } \\
15^{\circ} 09^{\prime} 49^{\prime \prime} \mathrm{N} ; 92^{\circ} 09^{\prime} 18^{\prime \prime} \mathrm{W} ; 1625 \text { masl }\end{array}$ \\
\hline Unión Roja & Mid & $\begin{array}{l}\text { Rural community located in a malaria-endemic region with agricultural activity, } \\
\text { mainly cultivation of coffee associated with other crops such as bananas and } \\
\text { timber. Humid warm climate with average annual rainfall of } 2158 \mathrm{~mm} \text { and } \\
\text { average annual temperature of } 26.6^{\circ} \mathrm{C} \text {. } \\
15^{\circ} 02^{\prime} 47.52^{\prime \prime N} \mathrm{~N} 92^{\circ} 12^{\prime} 58.50 " \mathrm{~W} ; 520 \text { masl }\end{array}$ \\
\hline $\begin{array}{c}\text { Buenos Aires } \\
\text { and } \\
\text { La Victoria }\end{array}$ & Low & $\begin{array}{l}\text { Rural communities located in malaria-endemic region with agricultural activity, } \\
\text { mainly banana, soybean, mango, and papaya among others (which have replaced } \\
\text { cotton crops). Warm humid climate with average annual rainfall of } 1337 \mathrm{~mm} \text { and } \\
\text { mean annual temperature of } 28.1^{\circ} \mathrm{C} \text {. Pest control in these zones is mainly based } \\
\text { on the use of pesticides. } \\
\qquad \begin{array}{l}14^{\circ} 53^{\prime} 20^{\prime \prime} \mathrm{N} ; 92^{\circ} 28^{\prime} 52^{\prime \prime} \mathrm{W} ; 20 \text { masl } \\
14^{\circ} 49^{\prime} 04^{\prime \prime} \mathrm{N} ; 92^{\circ} 29^{\prime} 47^{\prime \prime} \mathrm{W} ; 10 \text { masl }\end{array}\end{array}$ \\
\hline
\end{tabular}

\footnotetext{
* References: [1,21].
} 


\subsection{Selection of the Study Population and Sampling}

We held meetings with the civil and health authorities in each selected community to raise awareness about the study objective. Then, we requested the voluntary participation of villagers and obtained their signed informed consent. The volunteers answered a questionnaire that provided us with information on age, gender, occupation, working time, use and application of pesticides, and exposure time, among others. A total of 60 blood samples were collected from the three study regions, from individuals who met the following inclusion criteria: they must have lived for at least 5 years in the community and performed agricultural-related activities and/or belonged to a family unit performing agricultural activities. The sampling was conducted during August and September 2012.

A single blood sample (approximately $7 \mathrm{~mL}$ ) was drawn from each study participant by venipuncture of the cubital vein and was collected in heparin tubes. The samples were de-identified and appropriately labeled to maintain the confidentiality of the individuals involved in the project. Samples were then transported to the laboratory where plasma separation was achieved by centrifugation at $3000 \mathrm{rpm}$ for $10 \mathrm{~min}$. The plasma samples were then transferred using hexane-rinsed Pasteur pipettes to hexane-rinsed brown glass bottles. Plasma was stored at $-20{ }^{\circ} \mathrm{C}$ until analysis.

\subsection{Chemicals}

For validation and standardization of the analysis method, we used a mixture of standard-grade OC references from Ultra Scientific, which included the following analytes: aldrin, $\beta-\mathrm{HCH}, \alpha-\mathrm{HCH}$, $\gamma$-HCH, $\delta$-HCH, p,p'-DDD, p,p'-DDE, p,p'-DDT, dieldrin, $\alpha$-endosulfan, $\beta$-endosulfan, endosulfan sulfate, endrin, endrin aldehyde, heptachlor, and heptachlor epoxide. The organic solvents used for extraction of OC pesticides were HPLC-grade hexane, dichloromethane, acetone, and 99.97\% ethyl alcohol absolute, from J.T. Baker and Omni Solv.

\subsection{Extraction Method}

Pesticide residues were extracted according to the methodology proposed by Trejo-Acevedo et al. [22]. Two milliliters of plasma sample were used for liquid-liquid extraction with a mixture of absolute ethyl alcohol, ammonium sulfate, and hexane (1:1:3). The plasma sample and the mixture were mixed for four minutes using a vortex and then centrifuged at $3000 \mathrm{rpm}$ for eight minutes. Extraction was repeated with hexane for a total of four extractions, combining at the end all four extracts (organic phases) in concentrator tubes. Extracts were then concentrated in a rotary evaporator to one milliliter approximately. The concentrated extract was passed through a Baker Florisil column (1000 mg/6 mL) previously conditioned with six milliliters of dichloromethane, acetone, and hexane. The extract was eluted with six milliliters of dichloromethane:hexane (30:70). The eluent was collected in concentrator tubes and concentrated in a rotary evaporator to $500 \mu \mathrm{L}$ final volume approximately. The exact volume was estimated from the weight of the sample.

\subsection{Chromatography Method}

The extracts were analyzed by gas chromatography using a Perkin Elmer Clarus 500 gas chromatograph, equipped with an electron capture detector, autosampler, and a programmable 
split/splitless injector. The injection volume of extract was $2 \mathrm{~mL}$ in splitless mode. The initial temperature of the injector was $120^{\circ} \mathrm{C}$, and the speed of the carrier gas (hydrogen) was $48 \mathrm{~cm} / \mathrm{s}$. The detector temperature was $350{ }^{\circ} \mathrm{C}$, and the make-up flow was $30 \mathrm{~mL} / \mathrm{min}$. An Agilent J\&W DB-35MS column (p/n 122-3832) of $30 \mathrm{~m}$ length, $0.250 \mathrm{~mm}$ inner diameter, and $0.25 \mu \mathrm{m}$ film thickness was used. The initial oven temperature was $110^{\circ} \mathrm{C}$, which was maintained for $1.4 \mathrm{~min}$, followed by a temperature ramp with increments of $13{ }^{\circ} \mathrm{C} / \mathrm{min}$ up to $285{ }^{\circ} \mathrm{C}$, holding at $285{ }^{\circ} \mathrm{C}$ for $1 \mathrm{~min}$, another ramp of $30{ }^{\circ} \mathrm{C} / \mathrm{min}$ up to $300{ }^{\circ} \mathrm{C}$, and holding until the end of the routine $(3 \mathrm{~min})$. The total time of the analysis was $19.36 \mathrm{~min}$.

The linearity of the detector's response was evaluated by linear regression analysis of five different standard concentrations versus their response area. This generated calibration curves showing the relationship between analyte concentration and peak area. Quantification was performed by interpolation from these calibration curves. The identification of each compound in the samples was done by matching the retention time of the peaks in the chromatograms with the retention time of high purity standards. The limits of detection and quantification were determined by the least squares regression method using response data of nine standard solutions with concentrations near the lowest concentration covered by the calibration curves. The detection limits varied from $0.55-1.14 \mu \mathrm{g} / \mathrm{L}$, and the quantification limits between 1.78 and $3.79 \mu \mathrm{g} / \mathrm{L}$, depending on the pesticide. The percentage of recovery was estimated by spiking blank plasma samples with surrogate standards and then extracting and analyzing these samples following the methods described above. Recovery levels were in the range of $80 \%-102 \%$.

\subsection{Expression of OC Concentrations in Plasma Samples}

OC concentrations in plasma samples were expressed on a wet-weight basis as quantity per unit volume of serum $(\mu \mathrm{g} / \mathrm{L})$. The concentration of OC pesticides in blood plasma is usually reported on the basis of the wet-weight of the sample or adjusting for the lipid content. It is difficult to identify which method is the best but it has been reported that lipid adjustment increases the bias in the measurement [23,24].

\subsection{Statistical Analysis}

A descriptive analysis of the levels of OC pesticides was conducted by calculating geometric means, standard deviations, and minimum, maximum, and percentile values. OC pesticides not detected in at least $80 \%$ of the samples were excluded from further analysis. Significant differences between groups were determined by analysis of variance (ANOVA). A logarithmic transformation was performed prior to the analysis of means to meet the assumption of normality. $P$ values $<0.05$ were considered statistically significant. Statistical analysis was performed with the Statistica 7.0 software package, and graphs were made with SigmaPlot 10.

\section{Results}

\subsection{Sociodemographic Characteristics}

The average age of participants in the low and middle zones were 55.7 and 46.3 years, respectively, while in the high zone, the average was 37.4 years (Table 2). In the low and middle zones, we found 
individuals with the greatest durations of occupational exposure to pesticides: 33.1 and 27.5 years, respectively. Men constituted the largest group of participants, particularly in the low and mid-zones. In addition, we found a higher percentage of participants who were engaged in agricultural work in the low and mid-zones ( $91 \%$ and $83 \%$, respectively), compared to the high zone.

Table 2. Sociodemographic characteristics of the study participants.

\begin{tabular}{|c|c|c|c|}
\hline & $\begin{array}{c}\text { Low Zone }(n=22) \\
\text { Mean } \pm \text { SD* }(\text { Range })\end{array}$ & $\begin{array}{c}\text { Mid Zone }(n=18) \\
\text { Mean } \pm \text { SD* (Range) }\end{array}$ & $\begin{array}{c}\text { High Zone }(n=20) \\
\text { Mean } \pm \text { SD* (Range) }\end{array}$ \\
\hline Age (years) & $55.7 \pm 16.0(26.0-80.0)$ & $46.3 \pm 14.90(26.0-73)$ & $37.4 \pm 17.3(17.0-78.0)$ \\
\hline Occupational exposure (years) & $33.1 \pm 23.7(0-70.0)$ & $27.5 \pm 18.4(0-60.0)$ & $12.9 \pm 18.9(0-64.0)$ \\
\hline \multicolumn{4}{|l|}{ Gender (\%) } \\
\hline Male & 82.0 & 89.0 & 45.0 \\
\hline Female & 18.0 & 11.0 & 55.0 \\
\hline \multicolumn{4}{|l|}{ Occupation (\%) } \\
\hline Agriculturist & 91.0 & 83.0 & 45.0 \\
\hline Non-agriculturist & 9.0 & 17.0 & 55.0 \\
\hline
\end{tabular}

* Values expressed as geometric mean \pm standard deviation (SD).

\subsection{Organochlorine Pesticides in Plasma}

We detected seven $(\gamma-\mathrm{HCH}, \beta-\mathrm{HCH}$, heptachlor, $\beta$-endosulfan, endrin aldehyde, $\mathrm{p}, \mathrm{p}$-DDT, and p,p'-DDE) of the 16 organochlorine compounds tested for in the plasma samples (Table 3). Notably, p,p'-DDE was detected in $96.7 \%$ of the samples with a concentration of $24.66 \pm 45.63 \mu \mathrm{g} / \mathrm{L}$, followed by $\beta$-endosulfan in $38.3 \%$ of the samples. However, $\beta$-endosulfan did not reach the minimum detection frequency (at least $80 \%$ of samples), so we only used p,p'-DDE for subsequent analysis.

Table 3. Concentrations of organochlorine compounds in plasma samples from community residents of Soconusco, Chiapas, Mexico.

\begin{tabular}{|c|c|c|c|c|c|c|c|c|c|c|}
\hline \multirow[t]{2}{*}{ Analyte } & \multirow[t]{2}{*}{$\mathbf{n}$} & \multirow[t]{2}{*}{$\% \geq \mathrm{DL}^{\mathrm{a}}$} & \multirow[t]{2}{*}{$\mathbf{G M}^{\mathbf{b}}$} & \multirow[t]{2}{*}{ SD } & \multirow[t]{2}{*}{ Minimum } & \multicolumn{4}{|c|}{ Percentiles } & \multirow[t]{2}{*}{ Maximum } \\
\hline & & & & & & 25 & 50 & 75 & 90 & \\
\hline$\alpha-\mathrm{HCH}$ & 60 & 1.6 & nc & nc & $\mathrm{nc}$ & nc & $\mathrm{nc}$ & nc & nc & nc \\
\hline$\gamma-\mathrm{HCH}$ & 60 & 6.6 & 1.88 & 2.50 & 0.77 & 0.99 & 1.68 & 4.20 & 6.25 & 6.25 \\
\hline$\beta-\mathrm{HCH}$ & 60 & 13.3 & 4.60 & 2.10 & 2.03 & 3.78 & 4.38 & 6.42 & 8.74 & 8.74 \\
\hline Heptachlor & 60 & 11.6 & 2.94 & 1.12 & 1.74 & 1.88 & 3.67 & 4.02 & 4.40 & 4.40 \\
\hline$\delta$-HCH & 60 & 3.3 & nc & nc & nc & nc & $\mathrm{nc}$ & nc & nc & nc \\
\hline Aldrin & 60 & 0 & nd & nd & nd & nd & nd & nd & nd & nd \\
\hline $\begin{array}{l}\text { Heptachlor } \\
\text { epoxide }\end{array}$ & 60 & 0 & nd & nd & nd & nd & nd & nd & nd & nd \\
\hline$\alpha$-Endosulfan & 60 & 0 & nd & nd & nd & nd & nd & nd & nd & nd \\
\hline $\mathrm{p}, \mathrm{p}^{\prime}-\mathrm{DDE}$ & 60 & 96.7 & 24.66 & 45.63 & 1.1 & 12.2 & 31.6 & 64.9 & 112.4 & 222.6 \\
\hline Dieldrin & 60 & 1.6 & nc & nc & nc & nc & nc & nc & nc & nc \\
\hline Endrin & 60 & 0 & nd & nd & $\mathrm{nc}$ & nd & nd & nd & nd & nc \\
\hline $\mathrm{p}, \mathrm{p}^{\prime}-\mathrm{DDD}$ & 60 & 1.6 & $\mathrm{nc}$ & $\mathrm{nc}$ & $\mathrm{nc}$ & $\mathrm{nc}$ & $\mathrm{nc}$ & $\mathrm{nc}$ & $\mathrm{nc}$ & $\mathrm{nc}$ \\
\hline$\beta$-Endosulfan & 60 & 38.3 & 3.15 & 8.88 & 0.70 & 1.52 & 2.99 & 4.50 & 11.28 & 43.90 \\
\hline
\end{tabular}


Table 3. Cont.

\begin{tabular}{ccccccccccc}
\hline Analyte & $\mathbf{n}$ & $\mathbf{\%} \geq \mathbf{D L}^{\mathbf{a}}$ & $\mathbf{G M}^{\mathbf{b}}$ & $\mathbf{S D}$ & Minimum & \multicolumn{3}{c}{ Percentiles } & Maximum \\
\hline p,p-DDT & 60 & 15.0 & 14.71 & 8.95 & 6.37 & 9.18 & 15.16 & 24.91 & 29.66 & 29.66 \\
$\begin{array}{c}\text { Endrin } \\
\text { aldehyde }\end{array}$ & 60 & 11.6 & 2.87 & 2.52 & 0.51 & 0.71 & 5.17 & 6.13 & 6.76 & 6.76 \\
$\begin{array}{c}\text { Endosulfan } \\
\text { sulfate }\end{array}$ & 60 & 0 & $\mathrm{Nd} 2$ & nd & nc & nd & nd & nd & nd & nc \\
\hline
\end{tabular}

Plasma concentrations are reported in $\mu \mathrm{g} / \mathrm{L} ;{ }^{\text {a }} \%$ of samples with detectable levels; ${ }^{\mathrm{b}}$ values reported as geometric mean (GM); (SD) standard deviation; (nd) not detected; (nc) not calculated.

\subsection{Levels of p,p'-DDE per Zone}

In the low and middle zones, $100 \%$ of the plasma samples had levels of p,p'-DDE. The concentration of p,p'-DDE ranged between 9.8 and $222.6 \mu \mathrm{g} / \mathrm{L}$ with a mean of $50.6 \mu \mathrm{g} / \mathrm{L}$ in the low zone and between 4.5 and $114.1 \mu \mathrm{g} / \mathrm{L}$ with a mean of $54.46 \mu \mathrm{g} / \mathrm{L}$ in the middle zone. We found the highest levels of p,p'-DDE in both of these zones. In the high zone, $90 \%$ of the plasma samples had levels of p,p'-DDE ranging between 1.1 and $42.0 \mu \mathrm{g} / \mathrm{L}$ with a mean $4.4 \mu \mathrm{g} / \mathrm{L}$. Levels of p,p'-DDE found in the low and middle zones were significantly different $(p=0.0001)$ from that detected in the high zone (Figure 2). There was no significant difference between the levels in the low and mid zones. However, individuals with the highest levels of p,p'-DDE in plasma were found in the low zone.

Figure 2. Levels of p,p-DDE by zone, in plasma samples from community residents of Soconusco, Chiapas, Mexico. The letters "a" and "b" represent significant differences $(p<0.05)$.

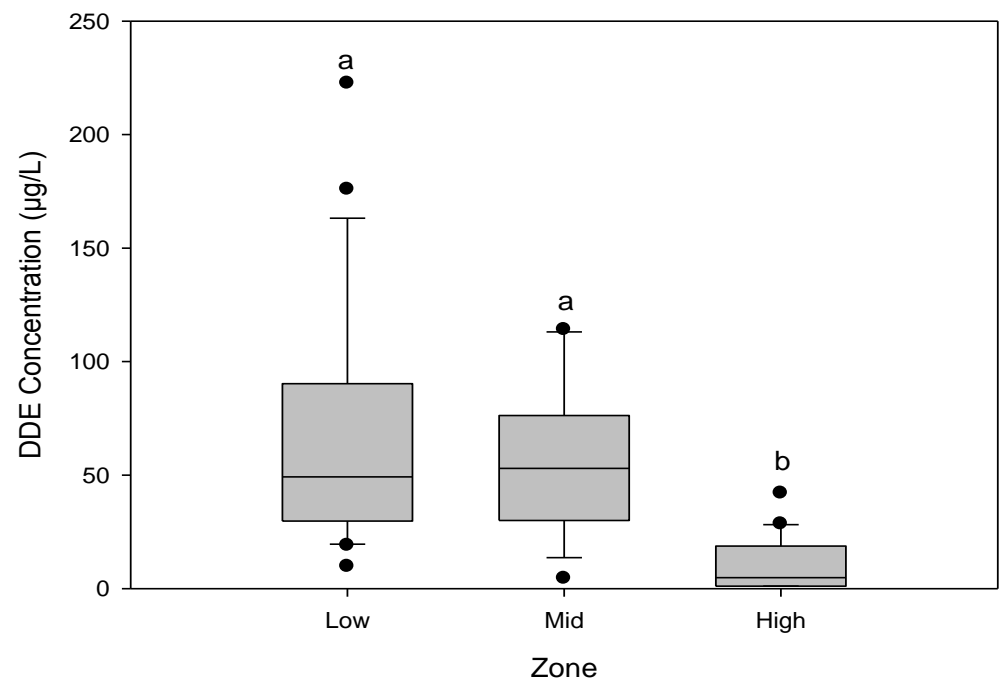

\subsection{Levels of $p, p^{\prime}-D D E$ by Age}

The level of p,p'-DDE in plasma increased with age (Figure 3). The group of older residents ( $>60$ years) had the highest level of p,p'-DDE $(56.94 \pm 57.81 \mu \mathrm{g} / \mathrm{L})$. The group of younger residents ( $<30$ years) had the lowest level $(5.88 \pm 23.68 \mu \mathrm{g} / \mathrm{L})(p=0.0006$, ANOVA). 


\subsection{Levels of p, $p^{\prime}-D D E$ by gender}

Men had higher plasma p,p'-DDE, with a mean of $34.00 \pm 46.76 \mu \mathrm{g} / \mathrm{L}$, compared to $6.21 \pm 29.69 \mu \mathrm{g} / \mathrm{L}$ in women (Figure 4). It should be noted that women accounted for $28 \%$ of the study population (Table 2 ).

Figure 3. Levels of $p, p^{\prime}-D D E$ by age, in plasma samples from community residents of Soconusco, Chiapas, Mexico. Bars with no common letters above them were significantly different $(p<0.05)$

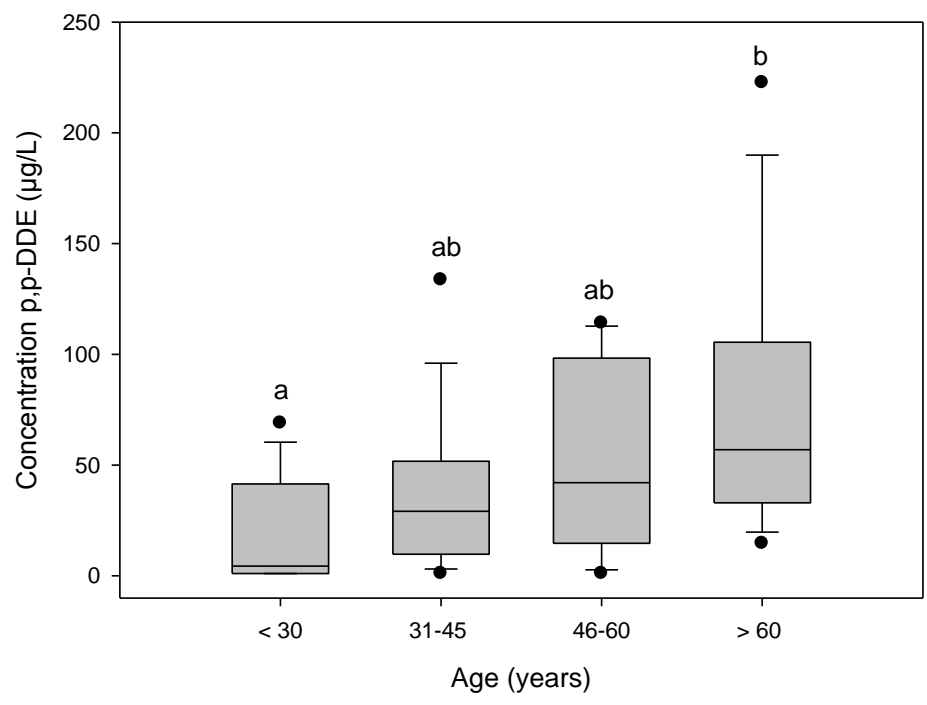

Figure 4. Levels of $\mathrm{p}, \mathrm{p}^{\prime}$-DDE by gender, in plasma samples from community residents of Soconusco, Chiapas Mexicn

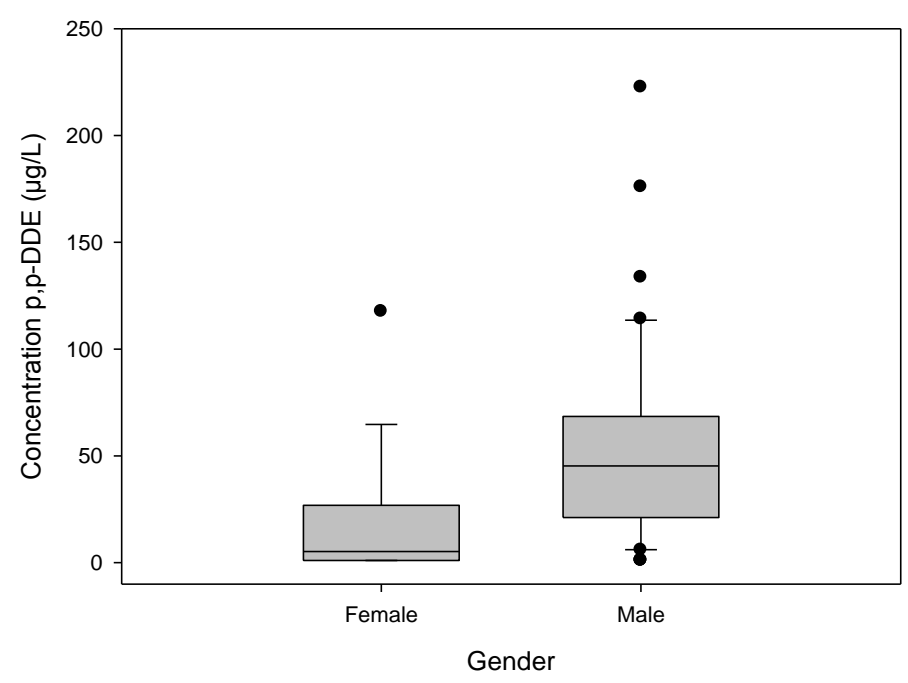

\section{Discussion and Conclusions}

Contamination by OC pesticides is an ongoing problem since these chemicals are persistent and some are still detected after many years of restriction or prohibition of use [14,25-28]. We found p,p'-DDT and p,p'-DDE in $15 \%$ and $96.7 \%$ of individuals sampled, respectively; while $\beta$-endosulfan was detected in $38.3 \%$ of them (Table 3). This is consistent with reports from other studies in southeastern Mexico, 
where $90 \%-100 \%$ of the surveyed population had detectable levels of p,p'-DDE [27-29]. Our results confirm the presence of DDT and DDE in blood of the population studied after almost 15 years of DDT use being forbidden in Mexico [3].

The ratio of DDT/DDE in the samples was calculated. DDT degrades to DDE and the DDT/DDE ratio can be used as a rough estimation of the length of existence of DDT. In general, a small value of the DDT/DDE ratio is indicative of aged DDT and a value much greater than one indicates fresh application [26]. In our study, the DDT/DDE ratio in the plasma samples was lower than one (0.60) which suggests a historical exposition to DDT. The predominance of p,p'-DDE as OC contaminant in plasma of the individuals sampled may be due to p,p'-DDT metabolism but it can also be the result of a currently lower environmental exposition to DDT and higher exposition to DDE. A decrease in the levels of p,p'-DDT in the Chiapas environmental has been reported by Waliszewski et al. [28].

Besides, $\beta$-endosulfan is the most persistent metabolite of endosulfan, and this pesticide is still used in Mexico, which could explain its detection. Importation of endosulfan was recently banned in Mexico, and its use is currently undergoing progressive elimination [30].

Our results were compared with those from other studies in adult populations, all of them reported on a wet-weight basis. Concentrations in whole blood, plasma and serum are compared (Table 4). No records were found for $\gamma-\mathrm{HCH}$ in adult populations of other regions of Mexico. However, this compound was detected in high concentrations (lipid-adjusted basis) in Mexican children [22]. The levels found in our study are 17-fold higher than those reported in China [31], are similar to those in Spain [32], and are 51-fold lower than the levels found in Nagaon, India [33]. Regarding $\beta$-HCH, the concentrations found in our study are higher than reported for Veracruz, Mexico [28]. When compared to values reported by the Fourth National Report on Human Exposure to Environmental Chemicals [34], our values are 70-fold higher. Compared to other countries, our $\beta$-HCH values are 15 -fold higher than in Spain [35], 166-fold lower than in India [36], and four-fold lower than in China [37]. In the case of Heptachlor, our results are 31-fold higher than those in China [31] but 558-fold lower than reported in India [36].

With regard to p,p'-DDE, our results are higher than reported in other regions of Mexico such as Veracruz [28] and the Federal District [38]. Compared to other countries, our results are 18-fold higher than in Brazil [39], three-fold higher than in Canada [40], four- and 18-fold higher than in Spain [32,35], and one-fold higher than in China [37]. Compared to levels reported by the CDC [34] for groups older than 20 years and for the Mexican-American population, our results are 14- and nine-fold higher, respectively. However, our p,p'-DDE levels are 27-fold lower than reported in India [36]. The levels of p,p'-DDT in our study are similar to those reported in Mexico's Federal District [38] but are higher than those found in Veracruz [28] and in other study in Chiapas [4]. Compared to other countries, our results are higher than in Spain [32,35], India [41], and China [31], but they are 107-fold lower than the contamination values in India, as reported by Mathur et al. [36].

With respect to $\beta$-endosulfan, we did not find national reports on the adult population. Comparing our results to pesticide levels in other countries, they are similar to those reported in Spain [32] and India [41] but 15-fold higher than those reported in China [31]. We found neither national nor international reports about endrin aldehyde (a metabolite of the endrin pesticide) on human populations. 
Table 4. Reported concentrations of organochlorine compounds in human plasma.

\begin{tabular}{|c|c|c|c|c|c|c|c|c|c|c|c|}
\hline Country & Population & Sample & Units $^{\infty}$ & $\gamma-\mathrm{HCH}$ & $\beta$-HCH & Heptachlor & p,p'-DDE & p,p'-DDT & $\beta$-endosulfan & $\begin{array}{c}\text { Endrin } \\
\text { Aldehyde } \\
\end{array}$ & Reference \\
\hline $\begin{array}{l}\text { Mexico } \\
\text { (Chiapas) }\end{array}$ & $\begin{array}{c}N=60 \\
\text { Men and Women }\end{array}$ & $\begin{array}{l}\text { Blood } \\
\text { plasma }\end{array}$ & $\mu \mathrm{g} / \mathrm{L}$ & $\begin{array}{l}1.88^{\mathfrak{f}} \\
2.60^{*}\end{array}$ & $\begin{array}{l}4.60^{£} \\
4.99^{*}\end{array}$ & $\begin{array}{l}2.94^{£} \\
3.13^{*}\end{array}$ & $\begin{array}{l}24.66^{£} \\
46.54^{*}\end{array}$ & $\begin{array}{l}14.71^{£} \\
19.96^{*}\end{array}$ & $\begin{array}{l}2.15^{\mathfrak{f}} \\
5.35^{*}\end{array}$ & $\begin{array}{l}2.87^{£} \\
4.06^{*}\end{array}$ & Our study \\
\hline $\begin{array}{l}\text { Mexico } \\
\text { (Chiapas) }\end{array}$ & $\begin{array}{c}N=30 \\
\text { Women }\end{array}$ & $\begin{array}{l}\text { Whole } \\
\text { blood }\end{array}$ & $\mu \mathrm{g} / \mathrm{L}$ & & & & 13.86 & 13.09 & & & {$[4]$} \\
\hline $\begin{array}{c}\text { Mexico }^{\hat{f}} \\
\text { (Veracruz) }\end{array}$ & $\begin{array}{c}N=150 \\
\text { Men and Women }\end{array}$ & $\begin{array}{l}\text { Blood } \\
\text { serum }\end{array}$ & $\mu \mathrm{g} / \mathrm{L}$ & & 1.5 & & 5.8 & 0.8 & & & {$[28]$} \\
\hline $\begin{array}{l}\text { Mexico } \\
\text { (Federal } \\
\text { District) }\end{array}$ & $\begin{array}{c}N=246 \\
\text { Woman cases } \\
\text { Woman control }\end{array}$ & $\begin{array}{l}\text { Blood } \\
\text { plasma }\end{array}$ & $\mu \mathrm{g} / \mathrm{L}$ & & & & $\begin{array}{l}24.2 \\
17.5\end{array}$ & $\begin{array}{l}1.05 \\
1.41\end{array}$ & & & {$[38]$} \\
\hline Brazil $^{*}$ & $\begin{array}{c}N=33 \\
\text { General population }\end{array}$ & $\begin{array}{l}\text { Blood } \\
\text { serum }\end{array}$ & $\mu \mathrm{g} / \mathrm{L}$ & & & & 2.5 & & & & [39] \\
\hline $\mathrm{CDC}^{£}$ & $\begin{array}{c}N=2500 \\
>20 \text {-year-old population } \\
\text { Mexican-American } \\
\text { Population }\end{array}$ & $\begin{array}{l}\text { Blood } \\
\text { serum }\end{array}$ & $\mu \mathrm{g} / \mathrm{L}$ & & 0.058 & & $\begin{array}{l}1.69 \\
2.69\end{array}$ & & & & {$[34]$} \\
\hline Canada $^{£}$ & $\begin{array}{c}N=101 \\
\text { General population }\end{array}$ & $\begin{array}{l}\text { Blood } \\
\text { serum }\end{array}$ & $\mu \mathrm{g} / \mathrm{L}$ & & & & 7.52 & & & & {$[40]$} \\
\hline Spain $^{£}$ & $\begin{array}{c}N=220 \\
\text { Young men }\end{array}$ & $\begin{array}{l}\text { Blood } \\
\text { serum }\end{array}$ & $\mu \mathrm{g} / \mathrm{L}^{\mathrm{a}}$ & 1.84 & & & 5.18 & 3.64 & 1.31 & & {$[32]$} \\
\hline Spain ${ }^{£}$ & $\begin{array}{c}N=283 \\
\text { General population }\end{array}$ & $\begin{array}{l}\text { Blood } \\
\text { serum }\end{array}$ & $\mu \mathrm{g} / \mathrm{L}$ & $<\mathrm{LD}$ & 0.3 & & 1.3 & 0.1 & $<\mathrm{LD}$ & & {$[35]$} \\
\hline India $^{*}$ & $\begin{array}{c}N=150 \\
\text { Woman Cases } \\
\text { Woman control }\end{array}$ & $\begin{array}{l}\text { Whole } \\
\text { blood }\end{array}$ & $\mu \mathrm{g} / \mathrm{L}^{\mathrm{b}}$ & $\begin{array}{c}713 \\
88\end{array}$ & $\begin{array}{c}832 \\
80\end{array}$ & $\begin{array}{c}1748 \\
84\end{array}$ & $\begin{array}{c}1293 \\
47\end{array}$ & $\begin{array}{l}2145 \\
1034\end{array}$ & & & {$[36]$} \\
\hline India $^{*}$ & $\begin{array}{c}\quad N=68 \\
\text { Postpartum women }\end{array}$ & $\begin{array}{l}\text { Whole } \\
\text { blood }\end{array}$ & $\mu \mathrm{g} / \mathrm{L}^{\mathrm{a}}$ & 5.23 & 10.05 & & 4.26 & 1.46 & 1.49 & & {$[41]$} \\
\hline India ${ }^{*}$ & $\begin{array}{l}\quad N=331 \\
\text { Dibrugarh Nagaon }\end{array}$ & $\begin{array}{l}\text { Whole } \\
\text { blood }\end{array}$ & $\mu \mathrm{g} / \mathrm{L}$ & $\begin{array}{c}49 \\
133\end{array}$ & $\begin{array}{l}119 \\
218\end{array}$ & & $\begin{array}{c}67 \\
144\end{array}$ & $\begin{array}{l}241 \\
203\end{array}$ & & & {$[33]$} \\
\hline China ${ }^{*}$ & $\begin{array}{l}N=250 \\
\text { Women }\end{array}$ & $\begin{array}{l}\text { Serum } \\
\text { blood }\end{array}$ & $\mu \mathrm{g} / \mathrm{L}$ & & 22.05 & & 34.5 & 1.4 & & & {$[37]$} \\
\hline China ${ }^{*}$ & $\begin{array}{l}N=1438 \\
\text { Women }\end{array}$ & $\begin{array}{l}\text { Serum } \\
\text { blood }\end{array}$ & $\mu \mathrm{g} / \mathrm{L}$ & 0.15 & 0.68 & 0.10 & 2.64 & 0.25 & 0.188 & & {$[31]$} \\
\hline
\end{tabular}

${ }^{\infty}$ All concentrations are reported on a wet-weigh basis; ${ }^{*}$ arithmetic mean; ${ }^{£}$ geometric mean; originally expressed: $\mathrm{ng} / \mathrm{mL}{ }^{\mathrm{a}}, \mathrm{mg} / \mathrm{L}{ }^{\mathrm{b}}$. 
The differences in exposure levels to OC pesticides among the above-mentioned countries is because developed countries such as Canada, Spain, and the United States restricted the use of OC pesticides in the 1970s. The legal framework in these countries is very strict regarding the use and application of pesticides, which contribute to adherence to such regulations [35]. In India, China, and Mexico, the use of most OC compounds was banned or restricted 34 years later, when the Stockholm Convention on Persistent Organic Pollutants came into force.

We found higher concentrations of p,p'-DDE (the main DDT metabolite) in the low and middle zones. Residents of the low zone in particular showed the highest levels of this compound (222.6 $\mu \mathrm{g} / \mathrm{L})$ (Figure 2). The zonal differences in p,p'-DDE levels could be explained by the history of DDT use in each area. As noted before, DDT was used in Soconusco for malaria control from 1957 until its ban in 2000 [42] and in agricultural crops until 1991 [43]. However, it is in the low zone where DDT was most intensively used for pest control, mainly in cotton cultivation [4]. Our data indicate that residents of the low zone were exposed to DDT as a result of its use in both malaria prevention and in agriculture. In contrast, residents of the mid-zone mostly used it in vector-control programs and to a lesser extent in agriculture. There is no record of DDT use for agriculture in the high area.

Other important factors contributing to the specific distribution of p,p'-DDE in the Soconusco region are the difference in altitude and the climatic factors in each zone, which favor the transport of pesticides from one location to another. Pesticides can be transported, in free form or associated with particles, to sites other than the application sites via the movement of water and air, and these transport routes can be cyclical [44]. Considering the year-round abundant rainfall in the high-altitude zone, the p,p'-DDT and/or p,p'-DDE may have been transported from higher-altitude zones to lower ones by the flow of water that washes off organic matter and sediments where pesticides have been adsorbed. On the other hand, the high temperatures of the low- and mid-altitude zones favor the volatilization of pesticides and their transport to higher altitudes by wind drag. In line with this, we should also consider that the population in the low and mid-zones could be regularly consuming p,p'-DDE-contaminated foods such as fish, milk, and meat, among other foods. As reported in a previous study in the low-altitude zone, fish consumption is an important route of exposure to $p, p^{\prime}$-DDT and p, $p^{\prime}-D D E$ [19].

Regarding the socio-demographic variables, we found that the level of p,p'-DDE increased with age. This is consistent with other studies reporting that age was associated with high levels of this DDT metabolite $[35,45]$. The same trend was demonstrated in the CDC report on samples collected during 2003-2004 [34]. According to that report, the age group $>20$ years had higher p,p'-DDE $(1.69 \mu \mathrm{g} / \mathrm{L})$ than the $12-19$-year-old group $(0.516 \mu \mathrm{g} / \mathrm{L})$. Our results could be explained by the fact that older residents had both occupational and environmental exposure when DDT was used in high amounts. DDT could have then been metabolized to p,p'-DDE which remains stored in people's tissues. Since the use of DDT was restricted in 1994 and forbidden more than 10 years ago, today younger residents are only environmentally exposed, mainly to DDE.

With respect to gender, men had higher p,p'-DDE $(34.00 \pm 46.76 \mu \mathrm{g} / \mathrm{L})$ than women. This result could be explained by the fact that men, in addition to being environmentally exposed like women, were more often occupationally exposed. On the other hand, women may have other routes of pesticide residue excretion that are not present in men, such as breastfeeding and menstruation, which helps lower their levels of OC compounds [33]. Our results are different from those reported by the CDC [34] in which similar levels of p,p'-DDE were detected in men $(1.45 \mu \mathrm{g} / \mathrm{L})$ and women $(1.46 \mu \mathrm{g} / \mathrm{L})$. This difference 
could be explained by the unequal representation of women and men in our study, while in the case of the CDC study both genders were equally represented. Furthermore, the levels reported by CDC are 23-fold lower than the levels detected in our study. This disagreement could be the result of differences in the exposure of the population to DDT in these countries since this pesticide was still used in Mexico many years after its ban in the United States.

In conclusion, our results show that residents of the studied communities in the Soconusco region of Mexico are widely exposed to p,p'-DDE. This is rooted in the large exposure to DDT in the past and the current environmental exposure to $\mathrm{p}, \mathrm{p}^{\prime}$-DDE. Notably, the residents from the low and middle zones could have a higher health risk because of exposure to this metabolite, compared to residents in the high zone. Further studies on the environmental monitoring of OC pesticides in the Soconusco region are required in order to identify the main sources and exposure routes to these pollutants.

\section{Acknowledgments}

We thank the community residents who participated in this study and Higinio López for preparing the map shown in Figure 1.

\section{Author Contributions}

Luz E. Ruiz-Suárez and Ricardo Bello-Mendoza initiated the study idea and developed the concept together with Ricardo A. Castro-Chan, Norma E. Rivero-Pérez, Antonio Trejo-Acevedo, Griselda K. Guillén-Navarro and Violette Geissen. Ricardo A. Castro-Chan contributed to chromatography analysis. Luz E. Ruiz-Suárez and Ricardo Bello-Mendoza drafted the manuscript. All authors contributed to and approved the final version of the manuscript.

\section{Conflicts of Interest}

The authors declare no conflict of interest.

\section{References}

1. Catalán, F.T. The Crisis of Cotton Production and the Expansion of Soybean Cultivation in the Soconusco Region of Chiapas, 1970-1988, 1st ed.; CIHMECH: Chiapas, Mexico, 1995; p. 126 (In Spanish).

2. Secretariat of Agriculture, Livestock, Rural Development, Fisheries and Food (SAGARPA). Cotton Crop, Cycle Spring-Summer 95/95 (In Spanish); SAGARPA: Chiapas, Mexico, 1995.

3. Pérez-Maldonado, I.N.; Trejo, A.; Ruepert, C.; Jovel, R.; Méndez, M.; Ferrari, M.; Saballos-Sobalvarro, E.; Alexander, C.; Yáñez-Estrada, L.; Lopez, D.; Henao, S.; Pinto, E.; Díaz-Barriga, F. Assessment of DDT levels in selected environmental media and biological samples from Mexico and Central America. Chemosphere 2010, 78, 1244-1249.

4. Herrera-Portugal, C.; Franco, G.; Reyes, K.; Rodriguez, M.; Schlottfeld, Y. Levels of DDT and DDE in blood of reproductive age women from Tapachula, Chiapas (Mexico). Hig. Sanid. Ambient. 2008, 8, 315-319 (In Spanish). 
5. Institute of Health, Environment and Labor (ISAT). Diagnostic of the Use of DDT in Malaria Control. Regional Inform for Mexico and Central America. Available online: http://www.cec.org/ files/PDF/POLLUTANSN/InfregDDTb_es.pdf (accessed 14 March 2014) (In Spanish).

6. Jung-Ho, K.; Yoon-Seok, C. Organochlorine pesticides in human serum. In Pesticides-Strategies for Pesticides Analysis; Stoytcheva, M., Ed.; InTech: Rijeka, Croatia, 2011.

7. International Agency for Research on Cancer (IARC). Monographs on the Evaluation of the Carcinogenic Risk of Chemicals to Man, 1991. Available online: http://monographs.iarc.fr/ENG/ Monographs/vol53/volume53.pdf (accessed on 20 April 2014).

8. Salazar-García, F.; Gallardo-Díaz, E.; Ceron-Mireles, P.; Loomis, D.; Borja-Aburto, V.H. Reproductive effects of occupational DDT exposure among male malaria control workers. Environ. Health Perspect. 2004, 112, 542-547.

9. Perez, R.N.; Trejo, A.; Perez, M.I.; Diaz-Barriga, F.; Rocha, A.D.; Yañez, E.L. Organochlorine pesticides exposure in children from the agricultural zone of San Luis Potosí, México. Epidemiology 2007, 18, doi: 10.1097/01.ede.0000276881.06361.e7.

10. Pérez-Maldonado, I.; Díaz-Barriga, F.; De la Fuente, H; González-Amaro, R.; Calderón, J.; Yañez, L. DDT induces apoptosis in human mononuclear cells in vitro and is associated with increased apoptosis in exposed children. Environ. Res. 2004, 84, 38-46.

11. Herrera-Portugal, C.; Ochoa-Díaz, H.; Franco-Sánchez, G.; Díaz-Barriga, F. DNA damage in children exposed to DDT in a malarious area of Chiapas, Mexico. Acta. Toxicol. Arg. 2005, 13, 12-16.

12. Rigneall-Hydbom, A.; Rylander, L.; Hagmar, L. Exposure to persistent organochlorine pollutants and type 2 diabetes mellitus. Hum. Exp. Toxicol. 2007, 26, 447-452.

13. Yañez, L.; Ortiz-Perez, D.; Batres, L.E.; Borja-Aburto, V.H.; Diaz-Barriga, F. Levels of dichlorodiphenyltrichloroethane and deltamethrin in humans and environmental samples in malarious areas of Mexico. Environ. Res. 2002, 88, 174-181.

14. Trejo-Acevedo, A.; Rivero-Pérez, N.E.; Flores-Ramírez, R.; Orta-García, S.T.; Varela-Silva, J.A.; Pérez-Maldonado, I. Assessment of the levels of persistent organic pollutants and 1-hydroxypyrene in blood and urine samples from Mexican children living in an endemic malaria area in Mexico. Bull. Environ. Contam. Toxicol. 2012, 88, 828-832.

15. Pérez-Maldonado, I.N.; Trejo-Acevedo, A.; Pruneda-Alvarez, A.G.; Gaspar-Ramírez, O.; Ruvalcaba-Aranda, S.; Perez-Vazquez, F.J. DDT, DDE, and 1-hydroxypyrene levels in children (in blood and urine samples) from Chiapas and Oaxaca, Mexico. Environ. Monit. Assess. 2013, 185, 9287-9293.

16. Alegria, H.A.; Wong, F.; Jantunen, L.M.; Bidleman, T.F.; Salvador-Figueroa, M.; Gold-Bouchot, G.; Moreno, C.V.; Waliszewski, S.M.; Infanzon, R. Organochlorine pesticides and PCBs in air of southern Mexico (2002-2004). Atmos. Environ. 2008, 42, 8810-8818.

17. Wong, F.; Alegria, H.A.; Bidleman, T.F. Organochlorine pesticides in soils of Mexico and the potential for soil-air exchange. Environ. Pollut. 2010, 158, 749-755.

18. Hernández-Romero, A.H.; Tovilla-Hernández, C.; Malo, E.A.; Bello-Mendoza, R. Water quality and presence of pesticides in a tropical coastal wetland in southern Mexico. Mar. Pollut. Bull. 2004, 48, 1130-1141. 
19. Herrera-Portugal, C.; Franco, G.; Bermudez, G.; Schottfeldt, Y.; Barrientos, H. Levels of DDT and metabolites (DDE and DDD) in fish for human consumption. Hig. Sanid. Ambient. 2013, 13, 1080-1085 (In Spanish).

20. Daly, G.L.; Lei, Y.D.; Teixeira, C.; Muir, D.C.; Castillo, L.E.; Wania, F. Accumulation of current-use pesticides in neotropical montane forests. Environ. Sci. Technol. 2007, 41, 1118-1123.

21. Grajales, M.; De la Piedra, R.; López, J. Biophysic and socioeconomic diagnostic in an intermediate and hill subriver basin Cohatán in the Soconusco, Chiapas. Avances en Investigación Agropecuaria 2008, 12, 29-44 (In Spanish).

22. Trejo-Acevedo, A.; Díaz-Barriga, F.; Carrizales, L.; Domínguez, G.; Costilla, R.; Ize-Lema, I.; Yarto-Ramírez, M.; Gavilán-García, A.; Mejía-Saavedra, J.; Pérez-Maldonado, I.N. Exposure assessment of persistent organic pollutants and metals in Mexican children. Chemosphere 2009, 74, 974-980.

23. Schisterman, E.F.; Whitcomb, B.W.; Louis, G.M.B.; Louis, T.A. Lipid adjustment in the analysis of environmental contaminants and human health risks. Environ. Health Persepect. 2005, 113, 853-857.

24. Hebert, C.E.; Keenleyside, K.A. To normalize or not to normalize? Fat is the question. Environ. Toxicol. Chem. 1995, 14, 801-807.

25. Martínez-Salinas, R.I.; Pérez-Maldonado, I.N.; Batres-Esquivel, L.E.; Flores-Ramírez, R.; Díaz-Barriga, F. Assessment of DDT, DDE, and 1-hydroxypyrene levels in blood and urine samples in children from Chiapas Mexico. Environ. Sci. Pollut. Res. Int. 2011, 19, 2658-2666.

26. Pérez-Maldonado, I.N.; Trejo-Acevedo, A.; Orta-García, S.T.; Ochoa-Martinez, A.C.; Varela-Silva, J.A.; Pérez-Vázquez, F.J. DDT and DDE concentrations in the blood of Mexican children residing in the southeastern region of Mexico. J. Environ. Sci. Health B 2014, 49, 87-93.

27. Torres-Dosal, A.; Martinez-Salinas, R.I.; Hernandez-Benavides, D.; Perez-Vazquez, F.J.; Ilizaliturri-Hernandez, C.; Perez-Maldonado, I.N. Assessment of the levels of DDT and DDE in soil and blood samples from Tabasco, Mexico. Environ. Monit. Assess. 2012, 184, 7551-7559.

28. Waliszewski, S.M.; Caba, M.; Herrero-Mercado, M.; Saldarriaga-Noreña, H.; Meza, E.; Zepeda, R.; Martinez-Valenzuela, C.; Gomez, A.; Villalobos, P. Organochlorine pesticides residues levels in blood serum of inhabitants from Veracruz, Mexico. Environ. Monit. Assess. 2012, 184, 5613-5621.

29. Waliszewski, S.M.; Aguirre, A.A.; Infanzon, R.M.; Silva, C.S.; Siliceo, J. Organochlorine pesticide levels in maternal adipose tissue, maternal blood serum, umbilical blood serum, and milk from inhabitants of Veracruz, Mexico. Arch. Environ. Contam. Toxicol. 2001, 40, 432-438.

30. Federal Commission for the Protection from Sanitary Risk (COFEPRIS). Actions for the Elimination of Endosulfan in Mexico (In Spanish). Mexico, 2013. Available online: http://0305.nccdn.net/ 4_2/000/000/089/98d/Acciones-para-la-eliminaci--n-de-endosulf--n-en-M--xico.pdf (accessed on 14 March 2013).

31. Cao, L.L.; Yan, C.H.; Yu, X.D.; Tian, Y.; Zhao, L.; Liu, J.X.; Shen, X.M. Relationship between serum concentrations of polychlorinated biphenyls and organochlorine pesticides and dietary habits of pregnant women in Shanghai. Sci. Total Environ. 2011, 409, 2997-3002.

32. Carreño, J.; Rivas, A.; Granada, A.; Lopez-Espinosa, M.; Mariscal, M.; Olea, N.; Olea-Serrano, F. Exposure of young men to organochlorine pesticides in Southern Spain. Environ. Res. 2007, 103, 55-61. 
33. Mishra, K.; Sharma, R.C.; Kumar, S. Organochlorine pollutants in human blood and their relation with age, gender and habitat from North-east India. Chemosphere 2011, 85, 454-464.

34. Centers for Disease Control and Prevention (CDC). Fourth National Report on Human Exposure to Environmental Chemicals. Department of Health and Human Services Centers for Disease Control and Prevention; National Center for Environmental Health: Atlanta, GA, USA, 2009.

35. Begoña, Z.; Aurrekoetxea, J.; Ibarluzea, J.; Goñi, F.; López, R.; Etxeandia, A.; Rodríguez, C.; Sáenz, B. Organochlorine pesticide in the general adult population of Biscay (Spain). Gac. Sanit. 2010, 24, 274-281 (In Spanish).

36. Mathur, V.; John, P.J.; Soni, I.; Bhatnagar, P. Blood levels of organochlorine pesticide residues and risk of reproductive tract cancer among women from Jaipur, India. In Hormonal Carcinogenesis V.; Li, J.J., Li, S.A., Mohla, S., Rochefort, H., Maudelonde, T., Eds.; Springer: New York, NY, USA, 2008; pp. 387-394.

37. Lee, S.A.; Dai, Q.; Zheng, W.; Gao, Y.T.; Blair, A.; Tessari, J.D.; Tian Ji, B.; Shu, X.O. Association of serum concentration of organochlorine pesticides with dietary intake and other lifestyle factors among urban Chinese women. Environ. Int. 2007, 33, 157-163.

38. Romieu, I.; Hernandez-Avila, M.; Lazcano-Ponce, E.; Weber, J.P.; Dewailly, E. Breast cancer, lactation history, and serum organochlorines. Am. J. Epidemiol. 2000, 152, 363-370.

39. Delgado, I.F.; Barretto, H.H.; Kussumi, T.A.; Alleluia, I.B.; Baggio, C. de A.; Paumgartten, F.J. Serum levels of organochlorine pesticides and polychlorinated biphenyls among inhabitants of Greater Metropolitan Rio de Janeiro, Brazil. Cad. Saude. Publica. 2002, 18, 519-524.

40. Philibert, A.; Schwartz, H.; Mergler, D. An exploratory study of diabetes in a First Nation community with respect to serum concentrations of p,p'-DDE and PCBs and fish consumption. Int. J. Environ. Res. Public Health 2006, 6, 3179-3189.

41. Pathak, R.; Suke, S.G.; Ahmed, R.S.; Tripathi, A.K.; Guleria, K.; Sharma, C.S.; Makhijani, S.D.; Mishra, M.; Banerjee, B.D. Endosulfan and other organochlorine pesticide residues in maternal and cord blood in North Indian population. Bull. Environ. Contam. Toxicol. 2008, 81, 216-229.

42. General Directorate of Epidemiology; Secretariat of Public Health and Services. Bulletin of Malaria and Other Vector Disseminated Diseases. Available online: http:/www.epidemiologia.salud.gob.mx/ doctos/boletin/1996/sem6.pdf (accessed on 25 July 2014)

43. Morales, R.; Cobos-Gasca, M. DDT and metabolites in Carey turtle eretmochelys imbricata (Linnaeus, 1766) eggs from the coast of Campeche State, Mexico. In Gulf of Mexico Pollution and Environmental Impact: Diagnostic and Tendencies (In Spanish), 2nd ed.; Botello, J.A.V., Osten, R., Gold-Bouchot, G., Agraz-Hernández, C., Eds.; Univ. Autón. de Campeche, Univ. Nal. Autón. de México, Instituto Nacional de Ecología: Campeche, Mexico, 2005; pp. 237-248.

44. Albert, A.; Benitez, A. Environmental impact of pesticides on coastal ecosystems. In Gulf of Mexico Pollution and Environmental Impact: Diagnostic and Tendencies, 2nd ed.; Botello, J.A.V., Osten, R., Gold-Bouchot, G., Agraz-Hernández, C., Eds.; Univ. Autón. de Campeche, Univ. Nal. Autón. de México, Instituto Nacional de Ecología: Campeche, Mexico, 2005; pp. 237-248 (In Spanish). 
45. Zumbado, M.; Goethals, M.; Alvarez-León, E.E.; Luzardo, O.P.; Cabrera, F.; Serra-Majem, L.; Domínguez-Boada, L. Inadvertent exposure to organochlorine pesticides DDT and derivatives in people from the Canary Islands (Spain). Sci. Total Environ. 2005, 339, 49-62.

(C) 2014 by the authors; licensee MDPI, Basel, Switzerland. This article is an open access article distributed under the terms and conditions of the Creative Commons Attribution license (http://creativecommons.org/licenses/by/4.0/). 